\title{
FLUID GENDER IDENTITIES IN JEANETTE WINTERSON'S SEXING THE CHERRY
}

\author{
Papatya ALKAN GENCA1
}

\begin{abstract}
A giant female dog breeder and an adventurous boy who constantly questions (his) existence and truth live through the turbulent times of the reign of Charles I. A "mad" female scientist and a confused young man in contemporary times cross paths. Neither of these pairs fit into the attributions to their respective gender identities. Through alternating narratives of these characters, Jeanette Winterson's Sexing the Cherry dwells on the questions of gender formation and linear flow of time and history. Indeed, gender expectations are repeatedly put into trial and are deconstructed throughout the text. The inscribed rewriting of the story of the twelve dancing princesses draws attention to the questions raised by the novel about gender, identity, and social construction of these two. Sexing the Cherry, in its narrowest sense, is the story of Jordan and the Dog Woman. There are two specific time/spaces: the first one is the seventeenth-century England during the reign of Charles I, and the second one is the twentieth-century England. In this respect, the second part of the novel moves forward (and also backward) in time, and presents the late twentieth-century versions of Jordan and the Dog Woman. In the body of all these characters, gender identity becomes a pluralized, fluid, and contingent concept. As such, this paper argues that Sexing the Cherry disrupts conventional representations and perceptions of gender (roles) through problematizing both the male and the female gender codes.
\end{abstract} subversion.

Keywords: Jeanette Winterson, Sexing the Cherry, gender, contingent,

\section{JEANETTE WINTERSON'IN SEXING THE CHERRY ADLI ROMANINDAKİ AKIŞKAN TOPLUMSAL CINSIYYET}

\section{ÖZ}

Dev bir köpek yetiştiricisi kadın ile sürekli olarak (kendi) varlı̆̆ı(nı) ve hakikati sorgulayan maceraperest bir erkek 1. Charles'ın çalkantılı krallığı sırasında yaşamaktadır. Günümüz dünyasında bir yerde, "deli" bir bilim kadınıyla kafası karışık bir genç erkeğin yolları kesişir. Bu iki çiftin hiçbiri kendilerine atfedilen toplumsal cinsiyet kimliklerine uymaktadır. Bu karakterlerin birbirini izleyen anlatıları vasitasiyla, Jeanette Winterson'ın Sexing the Cherry (Vişnenin Cinsiyeti) romanı toplumsal cinsiyet oluşumu, lineer zaman ve tarih soruları üzerinde durur. Gerçekten de metinde

\footnotetext{
${ }^{1}$ Yrd. Doç. Dr., Celal Bayar Üniversitesi, Fen Edebiyat Fakültesi, İngiliz Dili ve Edebiyatı Bölümü, papatyaalkan@yahoo.com.
} 


\section{Papatya Alkan Genca}

toplumsal cinsiyet beklentileri sürekli olarak yapıbozuma uğramakta ve sorgulanmaktadır. Metnin içine eklenmiş olan On İki Dans Eden Prenses hikayesinin yeniden yazımı, romanın toplumsal cinsiyet, kimlik ve bu ikisinin sosyal olarak inşasına dair sorduğu sorulara dikkat çeker. Sexing the Cherry, en dar manada, Jordan ve Dog Woman'ın hikayesidir. Metinde iki tane belirli zaman/mekan bulunmaktadır: on yedinci yüz yıl 1. Charles dönemi İngilteresi ve yirminci yüz yıl İngilteresi. Bu bağlamda, romanın ikinci kısmı zamanda ileri (aynı zamanda geri) gitmekte ve Jordan ile Dog Woman'ın yirminci yüz yıl versiyonlarını sunmaktadır. Bu karakterler üzerinden, toplumsal cinsiyet kimliği çoğul, sabit olmayan ve olumsal bir kavram haline gelmektedir. Böylelikle, bu makale Sexing the Cherry adlı romanın toplumsal cinsiyet (in) (rollerinin) geleneksel temsiliyet ve algılanışını hem erkek hem de kadın toplumsal cinsiyet kodları üzerinden problematize ettiğini savunmaktadır.

Anahta Kelimeler: Jeanette Winterson, Sexing the Cherry, toplumsal cinsiyet, olumsallık, ifsat.

\section{Introduction}

A giant female dog breeder and an adventurous boy who constantly questions (his) existence and truth live through the turbulent times of the reign of Charles I. A "mad" female scientist and a confused young man in contemporary times cross paths. Neither of these pairs fit into the attributions to their respective gender identities. Through alternating narratives of these characters, Jeanette Winterson's Sexing the Cherry dwells on the questions of gender formation and linear flow of time and history. Indeed, gender expectations are repeatedly put into trial and are deconstructed throughout the text. The inscribed rewriting of the story of the twelve dancing princesses draws attention to the questions raised by the novel about gender, identity, and social construction of these two.

Sexing the Cherry, in its narrowest sense, is the story of Jordan and the Dog Woman. There are two specific time/spaces: the first one is the seventeenth-century England during the reign of Charles I, and the second one is the twentieth-century England. In this respect, the second part of the novel moves forward (and also backward) in time, and presents the late twentieth-century versions of Jordan and the Dog Woman. In the body of all these characters, gender identity becomes a pluralized, fluid, and contingent concept. As such, this paper argues that Sexing the Cherry disrupts conventional representations and perceptions of gender (roles) through problematizing both the male and the female gender codes.

Laura Doan contends that "fiction, for Winterson, is the site to interrogate, subvert, and tamper with gender, identity, and sexuality; her fiction is a serious invitation to imagine the emancipation of 'normal' and 'natural' from the exclusive and totalizing domain of 
patriarchal and heterosexual authority" (1994: 154). The question of gender, identity, and sexuality has been a recurrent theme in many, if not all, of Winterson's novels such as The Passion, The Powerbook, and Written on the Body, just to name a few. However, Sexing the Cherry proves to be the most overt text that concentrates on these issues in its technical and thematic dimensions. According to Lisa Moore, "the protagonists of this novel either move between and among gender and sexual identifications (Jordan), or simply exceed them (his foster mother, the Dog Woman). Once again, an understanding of the malleability of gender and sexual boundaries characteristic of the point of view of a marginalized sexuality is represented not as a minority position, but as the unproblematic possession of the novel's most admirable characters" (1995: 116). This paper puts into context what conventional gender representations and perceptions denote, and it sets out to demonstrate how these are put in brackets in Sexing the Cherry. Fluid gender identities are highlighted in the text in four basic manners: (a) fruit symbolism, (b) subversion of conventional male and female attributes, (c) historical (re)contextualization, and (d) rewriting of fairy tales.

\section{Fruit Symbolism}

According to Jane Pilcher and Imelda Whelehan, "the concept of gender, as we now use it, came into common parlance during the early 1970s. It was used as an analytical category to draw a line of demarcation between biological sex differences and the way these are used to inform behaviors and competencies, which are then assigned either as 'masculine' or 'feminine'" (2004: 56). Such demarcation brings into the conceptualization of gender a political, ideological, and sociological dimension. In this sense, "rather than natural biology determining men's and women's bodies as different, masculine and feminine bodies are largely made as such through cultural practices" (Pilcher and Whelehan, 2004: 9). Gender turns into a naturalized, doxified concept through reiterated codes and images. Sexing the Cherry problematizes this naturalized conceptualization of gender even at the beginning of the text with its unconventional fruit symbolism.

The novel opens with Jordan introducing himself: "My name is Jordan. This is the first thing I saw" (SC 9). This first thing he mentions is a pineapple, which is depicted in the form of a drawing at the top of each section where Jordan is the narrator. Whenever the narrator changes, so does the image on the page; if it is the Dog Woman speaking, then the image is a banana. Through the end of the novel, when the time/space turns into a contemporary one, both the 


\section{Papatya Alkan Genca}

banana and the pineapple are drawn as split into two. The change from intact to split can be explained in Lacanian terms: that the self is a whole and indestructible entity had been challenged with Freud's tripartite model of human psyche is further problematized by Jacques Lacan. Lacan maintains that it is through language that the self conditions itself as a human being and part of the social realm (2005: 40). Likewise, gender is defined and shaped like a linguistic entity. Whereas the self, represented by either a pineapple or a banana, is intact when the story takes place in the seventeenthcentury England of Charles I, it is split when the story steps into the twentieth century. The use of fruit as an indicator of sex or gender is nothing new, and "fruit has always stood as a metaphor for sexuality" (Makinen, 2005: 84); however, in Sexing the Cherry it is used explicitly and deliberately to refer to the problematic nature of identity and gender formation by "aligning each character with a fruit against conventional expectations" (Doan, 1994: 11). Conventionally, of course, banana would be more appropriate to represent a male figure because of its phallic connotation. Likewise, a pineapple would be more suitable to represent a female figure since its roundness is similar to the female shape. By choosing to frustrate expectations, Winterson draws attention to the constructedness of gender representations. In this sense, fruit symbolism calls into question both traditional conceptualizations of gender and monolithic/singularized depictions of self.

In terms of gender formation and identity construction, another significant fruit symbolism in the novel can be observed in the act of grafting, which is also what the novel is named after. Grafting is "the means whereby a plant, perhaps tender or uncertain, is fused into a hardier member of its strain, and so the two can take advantage of each other and produce a third kind, without seed or parent" (SC 78). In her article "Multiple Selves and Grafted Agents," Bente Gade argues that "[t]hrough the metaphor of grafting, Winterson represents identity as radically fragmented and multiple and in consequence dependent upon construction" (1999: 36). Grafting, through its act of reproduction, points at the constructed nature of gender, and offers a third alternative to the already available, yet rigidified and dichotomous gender roles, it creates a hybrid "third sex, a fusion of diverse strains" (Doan, 1994: 12). In the text, characters defy "normal" patterns of identity and gender, which can be read as an offer of an alternative, something that does not have to be either this or that, but can exist being neither or both. In this sense, grafting becomes a symbolic alternative to dichotomies of man and woman, masculine and feminine, male and female.

24 | Celal Bayar Üniversitesi Sosyal Bilimler Dergisi - Cilt: 13, Sayı: 3, Eylül 2015 


\section{Subversion of Conventional Male and Female Attributes}

The novel also subverts conventions about gender. Conventional gender representations and conformist gender identities are problematized in the characters of the Dog Woman and the nameless female scientist. Neither the Dog Woman nor the unnamed scientist falls into the stereotypical image of womanhood. The Dog Woman, who is denied a proper name but called after her profession, has a grotesque image: "I know people are afraid of me, either for the yapping of my dogs or because I stand taller than any of them, when I was a child my father swung me up on his knees to tell a story and I broke both his legs" (SC 25). As such, she is both powerful and intimidating, both a giant physical existence and a fearsome image. She evidently does not fit into to conceptualization of "fair sex." She is not a beauty symbol, nor is she a temptress. She evokes neither other-worldly purity (like Virgin Mary) nor worldly temptation (like Eve). The long existing dual portrayal of women either as Eve, corrupt and someone to stay away from, the devil's handmaid, or Virgin Mary, a larger-than-life purity symbol is challenged in the body of the Dog Woman. In this respect, Sexing the Cherry poses serious questions at the dichotomic cluster women seem to be trapped in its portrayal of the Dog Woman. Such dichotomic clustering is especially manifest in her relationship with the opposite sex. First, she takes a fancy at a man who cannot help but faint after his confrontation with this gigantic woman:

I presented myself to my loved one, who graced me with all of his teeth at once and swore that if only he could reach my mouth he would kiss me there and then. I swept him from his feet and said, 'Kiss me now,' and closed my eyes for the delight. I kept them closed for some five minutes and then, opening them to see what had happened, I saw that he had fainted dead away. I carried him to the pump that had last seen my devotion and doused him good and hard, until he came to, wriggling like a trapped fox, and begged me to let him down. (SC 36)

Instead of being the passive recipient of sex and intimacy, she becomes the active agent in the relationship. Elizabeth Langland notes that " $\mathrm{t}] \mathrm{he}$ Dog Woman's performance of gendered traits of tenderness, charity, and the maternal reveals the extent to which those things seen as inherent to women and to femininity are produced within a cultural context that scripts behavioral norms out of relative size, mass, and strength" (1997: 102). Her physique makes it impossible for her to act feminine, to be seen as fragile and fair, and the accompanying feminine traits Langland mentions highlight the 


\section{Papatya Alkan Genca}

contingent nature of gender, and "destabilizes the conventional meanings of those terms and exposes their cultural construction" (Langland, 1997: 103). Indeed, for all intents and purposes, she behaves in a rather masculine way, "[t]he example of the Dog Woman makes it clear that possessing a body sexed female is not what defines one as a woman" (Watkins, 2000: 157). Makinen also marks how the Dog Woman represents an ambiguous position where sex and gender clash and collide instead of complementing each other: "[t]he Dog Woman's performance of traditional feminine traits serves to destabilize them as 'natural' to women. For the Dog Woman is indisputably female by sex, but is not feminine by gender, since no man can impregnate her and her size confounds them" (2005: 99). In another instance, she comes across another man who tries to persuade her to perform fellatio for him. She depicts the incident offhandedly, and also mentions her failed intercourse with another man in the following pages of the novel. In all cases, she says that she is not overcome by ecstasy. Moreover, her mother has informed her that "men take pleasure and women give it" (Winterson, 1989: 107). Yet, her larger-than-life physique makes it impossible for her to be categorized as the object of reception. It continuously turns into a threatening presence instead, resolutely marking her as the other: not only as the other for men but as the other for the accepted portrayals of female identities. The Dog Woman does not and cannot conform to the norms of a patriarchal society, and she stands out both with her physical appearance and by her inability to yield to the "male power."

Her physical otherness is overtly emphasized when she asks, "How hideous am I?" (Winterson, 1989: 24). She seems to take her "hideousness" for granted, rather than questioning it or even doubting it. Her identity oscillates between "oversized, ruthless female serial killer" and "enviable strong and independent woman" (Bartholmess, 2013: 6). In both scenarios, she stands out as the outof-norm, unacceptable, and abnormal. In a society which openly or covertly feeds up an image of proper womanhood both through preferred physical appearance (slim, curvy, petite, etc.) and through preferred behavior patterns (meek, submissive, gentle, etc.), the Dog Woman fails on both accounts. Rather than subscribing to these accepted ideas and ideals, the Dog Woman comes to the fore as a disruptive figure.

The nameless scientist can be considered to be the alter-ego of the Dog Woman, and vice versa. Although there is no physical similarity between the two, their non-conformity binds them together. The chemist conceives herself in Rabelaisian dimensions: "I

26 | Celal Bayar Üniversitesi Sosyal Bilimler Dergisi - Cilt: 13, Sayı: 3, Eylül 2015 
had an alter-ego who was huge and powerful, a woman whose only morality was her own and whose loyalties were fierce and few" (Winterson, 1989: 125). This alter-ego curiously resembles the Dog Woman of the seventeenth century. Bente Gade argues that "Sexing explores different ways of understanding time and materiality - and stresses the interrelatedness of these co-ordinates in relation to identity" (1999: 35). Although seemingly different persons in different time dimensions, there is a parallelism between the Dog Woman and the chemist, and between Jordan and Nicholas. Greg Clingham also notes the similarity between these two sets of characters as follows: "[t]he modern characters become a kind of historical echo of the seventeenth-century figures, speaking in a hybrid language that while their own, also bears uncanny traces of the speech of the seventeenth-century Dog Woman and Jordan" (1998: 69). In this respect, identity becomes a patchwork of different and scattered pieces while material body is freed from time's bondage. The female chemist is as misfit as the Dog Woman is:

As a chemist with a good degree, and as an attractive woman whom men like to work with, I could have taught in a university or got a job doing worthy work behind the scenes. I needn't have gone into pollution research. It's odious in every way. Big companies hate you and continually send their in-house scientists to discredit your facts.

'Why don't you work for ICI?' my father said. 'They've got a share-option scheme.'

Yes, why don't I, or Shell, or Esso, or Union Carbide, or NASA? (Winterson, 1989: 125) (italics mine)

Whereas the Dog Woman is a physical threat, the scientist becomes an intellectual threat to the established gender categories by refusing to follow what is expected of her gender: she is unmarried, she works at a job that is not considered "cool," and she does not let others reduce her to an attractive woman who has decorative rather than any real value. All these mark her as a nonconformist just like the Dog Woman and Jordan.

\section{Historical (Re)contextualization}

The novel's historical setting(s) help underscore its problematization of gender. The historical background supplies the text with the necessary comparison between two different mindsets which are represented by the sexually hysterical Puritans such as Preacher Scroggs and Neighboor Firebrace and the non-conformists like the Dog Woman and Jordan. The Puritans' abhorrence with anything or anyone that is different provides a good basis for the juxtaposed non-conformity of the novel's protagonists. The 


\section{Papatya Alkan Genca}

juxtaposition is most evident in the matters related to body and sex. Clingham suggests that the Puritans' "denial and perversion of the sexual body is a manifestation of their moral self-righteousness" (1998: 71). Winterson points at the hypocrisy of the Puritans and seems to contend that suppression can only result in aggression and reinforcement:

I've seen Puritans going past a theatre where all was merriment and pleasure and holding their starched noses for fear they might smell pleasure and be infected by it.

[...]

I heard from his [Preacher Scroggs'] wife that he makes love to her through a hole in the sheet.

'Does he not kiss you?'

'He has never kissed me,' she answered, 'for fear of lust.'

Then lust must be a powerful thing, if to kiss her that most resembles a hare, with great ears and staring eyes, bring it on.

It is a true saying, that what you fear you find. (Winterson, 1989: 26-7)

In another instance, the Dog Woman depicts the Puritans as follows: "[t]he Puritans, who wanted the rule of saints on earth, and no king but Jesus, forgot that we are born in flesh and in flesh must remain. Their women bind their breasts and cook plain food without salt, and the men are so afraid of their member uprising that they keep it strapped between their legs with bandages" (Winterson, 1989: 67). In a larger context, both the historical data and the issue of sexuality are bound together in the framework of seventeenthcentury English society. As the name suggests, Puritans are concerned with the idea of "purification;" historically speaking, "they sought to 'purify' the Church of England" ("Puritanism"). It also had cultural and social repercussions as their ideas also seeped into the social domain in the form of restrictions and a frowning-upon pleasure: "[t]o the Puritans, a person by nature is inherently sinful and corrupt, and only by severe and unremitting discipline could they achieve good [...] They also laid emphasis on constant selfexamination and self discipline" (Kang, 2009: 149). This self discipline starts with the flesh; thus, it comes as no surprise that the Dog Woman, who is omnipresent with her gigantic body, is the representative of flesh, something terrifying but at the same time unavoidable. She also becomes the representative of the Puritans' loath and refusal of the flesh because she is made explicitly present, both due to her proportions and her gender, undermining the 
expectation of that particular society in which women should be "invisible" and submissive.

While many critics such as Ute Kauer, Paulina Palmer, Rebecca O'Rourke, and Lucie Armitt have noted the contested feminine identities and representations in Sexing the Cherry, it must also be acknowledged that an equally valid contestation has been performed through the male narrators and their depictions in the text. Feminism has been critically interrogating the relationship between women and the patriarchal system. It has also focused on such important questions as to how women are depicted and subjugated within such a system. While there is a plethora of literature (Gilbert and Gubar, 1979; Friedan, 1963; de Beauvoir, 1949 , just to name a few) on the relationship between women and patriarchy, recent studies also call into question the suppressive or limiting effect of the patriarchal mindset on men (e.g. Donald, 2011; Adams and Savran, 2002; Connell, 1995). Indeed, Sonya Andermahr draws attention how Winterson's "depiction of men [...] merits critical analysis in its own right and, far from reproducing stereotypes of masculinity, represents a complex and nuanced meditation on forms of male identity" (2007: 10). Merja Makinen also notes that "The character of Jordan is, like so many of Winterson's characters, not satisfied with narrow binary stereotypes of masculinity and femininity" (2005: 88). Both Jordan of the seventeenth century and Nicholas Jordan of contemporary times struggle with the limitations of "masculinity" imposed upon them by society. Sexing the Cherry recognizes the limitations and expectations put for men in society as can be observed in Jordan's depiction of women. His relationship with men is not a hierarchically superior one; rather, he has been taught to be careful around women, not because they are less than men or should be regarded as inferior, but because their code of communication and making sense of the world is significantly different from that of men: "I watched women flirting with men, doing business with men, and then I watched them collapsing into laughter, sharing the joke, while the men, all unknowing, felt themselves the master of the situation and went off to brag in barrooms and to preach from pulpits the folly of the weaker sex" (Winterson, 1989: 31-2). Jordan observes women - a position that indicates exteriority - and seems to have intimate knowledge of how men feel - a position that indicates interiority. As such, one may incline to think that Jordan is a man and not a woman. However, he does not stand out as a traditional male figure but as a genderless character trying to find his way out. He even crossdresses at some point during one of his fantastic journeys, which, as 


\section{Papatya Alkan Genca}

Makinen points out, "allows him an insight into women's private language and enables him temporarily to escape the burdens of living up to gender expectations" (2005: 91). However, this is not a permanent state; cross-dressing situates him on a threshold position which is neither here nor there. Even his name contributes to his ambiguous gender position as Jordan is a unisex name, which can be used for both girls and boys. His various journeys to fantastic places turn into a quest in which Jordan tries to find his true self, which proves to be elusive.

In the twentieth-century setting, Nicholas Jordan is presented in a struggle with society about expected gender behavior, too. He finds it difficult to reconcile his sense of self with the demanded self of society. Nicholas is expected to be ambitious, when he tells his friend, Jack, that he wants to be a sailor, Jack dismissively retorts that he is "too old for this boat stuff" (Winterson, 1989: 119), because as a "man," he should find a career path that leads him to a steady income, a secure social position, and a "manly" occupation. Boats and sailing is for boys, not for men. He appropriates his desire by becoming a naval cadet. However, his narrative also makes it clear that he is not interested in the idea of becoming part of the navy for the sake of glory-seeking or in the name of having a hero complex but he sees it as an opportunity to explore not only other lands, but also his true self.

\section{Rewriting of Fairy Tales}

In addition to the problematized gender identities as reflected in the main characters, the inscription of a fairy tale within the body of the novel draws attention to how fairy tales can serve as reinforcement of expected and normalized gender behavior, and how these can be subverted in a postmodern retelling. Grice and Woods notes how "Winterson exhibits the concern to use - and abuse representations of women inherited from older and other narrative modes like mythology, folklore and fairy tale" (1998: 6). The story of Orion and Artemis, several references to various fairy tales and stories such as Rapunzel and the Frog Prince are all inscribed within the text. However, the most overt and significant rewriting is the retelling of the story of the twelve dancing princesses, "who lived happily ever after, but not with their husbands" (Winterson, 1989: 48). Deviating from the original story, Winterson gives voice to the princesses in Jordan's narrative. Jordan seeks Fortunata the youngest of the princesses, and comes across the others each of whom tell their version of the story. It is true that they slip off the palace they live to go to a mystic place to dance all night long; and that finally a prince, after finding out their secret, asks the hand of the youngest

30 | Celal Bayar Üniversitesi Sosyal Bilimler Dergisi - Cilt: 13, Sayı: 3, Eylül 2015 
princess. His brothers, conveniently, end up marrying the other princesses:

You know that eventually a clever prince caught us flying through the window. We had given him a sleeping draught but he only pretended to drink it. He had eleven brothers and we were all given in marriage; one to each brother, and as it say lived happily ever after, but not with our husbands.

[...]

For some years I did not hear from my sisters, and then, by strange eventuality, I discovered that we had all, in one way or another, parted from the glorious princes and were living scattered, according to our tastes. (Winterson, 1989: 48) (Italics mine)

Fairy tales are part of oral tradition, passed from one generation to the other, usually through a female interlocutor. They transcribe a moral and social message mostly with respect to the roles of each gender within society. In this sense, they are the facilitators of what Judith Butler calls "gender performance" in that they enable children consciously or subconsciously to yield to the "correct" performative role pertaining to their respective gender. These cultural practices lie at the center of Judith Butler's idea of gender identity which is constituted solely by "the expressions of gender; [...] identity is performatively constituted by the very 'expressions' that are said to be the results" (2007: 25). These expressions are also reiterated through tales and folklore. Fairy tales end with reconciliation, which is more often than not in the form of marriage. Yet, fairy tales come to a closure without reflecting on what comes after marriage or how marriage transforms the supposedly celebrated ending. In her rewriting of the fairy tale, Winterson goes further than merely presenting a conventional one in which the couple lives happily ever after and she shows alternative sequels to the original story. Indeed, Winterson's rendition of the fairy tale illustrates "the arbitrary unnaturalness of normal gender relations" (Makinen, 2005: 91). The expected submission on part of the woman is realized in none of these marriages; one falls in love with a mermaid, one kills her husband because he has tried to stop her hobby of collecting religious items, another kills her husband because he was in love with a boy, one leaves her husband because of his extramarital affairs, one has a husband who has turned into a frog by the first kiss he gets from her, one leaves the house getting sick of household chores, one of the princesses' husband turns out to be a woman with whom she lives perfectly happily until someone realizes this and kills her, another kills her husband for eating too much, one' 


\section{Papatya Alkan Genca}

husband turns her into a killer bird and one day she kills him being what she is, and the last one's husband asks the princess to kill him because he has found life unbearable.

In all these stories, women in marriage are happy only when they are with another woman, as in the case of the first and the seventh princess, and they either kill or leave their husbands when they are with men. In this respect, marriage as an institution does not offer the perfect cohabitation for men and women, and most of the time, it becomes a burden on part of the female party. In the case of the princess whose husband is being unfaithful, for example, when she asks him to leave, he "very patiently [asks] me to remember that the house [is] his home, that he [cannot] be expected to make himself homeless because he [is] in love" (Winterson, 1989: 58). Then, she lists her options:

I could stay here and be unhappy and humiliated.

I could leave and be unhappy and dignified.

I could beg him to touch me again.

I could live in hope and die in bitterness.

I took some things and left. It wasn't easy, it was my home too. (Winterson, 1989: 58)

By listing her options, the princess actually lays bare the possible options women may have in such a situation, and other princesses' stories also underscore the limits imposed to women in society: "[ $\mathrm{t}$ ]he various narratives assigned to them [the princesses] highlight the social and economic power which men wield and the brutal punishments which they inflict on women if they dare to transgress the conventional role of object of exchange" (Palmer, 1993: 104-5). The presence of a traditional male figure is depicted as an oppressive one who either puts limits to (or simply bans) the wishes and desires of a woman, or someone who does not know what a woman may want or think of. As such, the tales, in their subversive narratives, provide alternative directions for women while drawing attention to how limiting the present situation is.

There are eleven stories told consecutively, which means that there is a missing princess, the one Jordan has been looking for. Instead of following suit and getting married like her sisters have done, Fortunata runs away to shape her own fortune. By so doing, she refuses to be defined by and through a male companion under the name of marriage. Marriage is one of the core institutions which ensure the continuation of a heterosexual and patriarchal order. Fortunata's refusal to yield to the system marks her as another nonconformist in the text becomes a possible alternative to the heterosexual and patriarchal system where each gender is closely

32 | Celal Bayar Üniversitesi Sosyal Bilimler Dergisi - Cilt: 13, Sayı: 3, Eylül 2015 
associated with a series of behavior patterns and conduct. Evidently, Fortunata and her sisters in Sexing the Cherry become a disruption to the heteronormative discourse prevalent in fairy tales.

\section{Conclusion}

Conventional thought presumes a binary conceptualization of gender as male and female. Thinking of gender as a dichotomous concept, as something inherently divided into man/woman, male/female, masculine/feminine binaries, however, "reduces the richness and complexity in the interest of logical neatness" (qtd. in Pilcher and Whelehan, 2004: 25). There are no clear-cut, black and white demarcations. If gender is a cultural construct that regulates individuals, then it is possible to reconstruct and even deconstruct the process, which is what Sexing the Cherry sets out to do. It points at the possibility of a less contoured and more fluid sense of gender, and thus, of gender identities. Sexing the Cherry takes up taken-forgranted notions, concepts, and even images, and subverts them in such a way so as to draw attention to their discursive, hence constructed nature.

\section{REFERENCES}

ANDERMAHR, Sonya (2007), Jeanette Winterson: A Contemporary Critical Guide, Continuum, New York.

BARTHOLMESS, Katja, "Female Self-Representation in Jeanette Winterson's Sexing the Cherry." <www.grin.com.en/ebook/107895/female-self-representation-in-jeanette-winterson-ssexing-the-cherry> (March 10, 2013).

BUTLER, Judith (2007), Gender Trouble: Feminism and the Subversion of Identity, Routledge, London and New York.

CLINGHAM, Greg (1998), “Winterson's Fiction and Enlightenment History," Questioning History: The Postmodern Turn to the Eighteenth Century. Ed. Greg Clingham. Bucknell University Press, Lewisburg, pp. 57-85.

DOAN, Laura (1994), “Jeanette Winterson's Sexing the Postmodern," Lesbian Postmodern. Ed. Laura Doan. Columbia University Press, New York, pp. 137-55.

GADE, Bente (1999), "Multiple Selves and Grafted Agents: A Postmodern Reading of Jeanette Winterson's Sexing the Cherry," Sponsored by Demons: The Art of Jeanette Winterson. Eds. Helena Bengston et al. Scholar's Publishing, Sweden: Scholar's, pp. 27-40.

GRICE, Helena and Tim Woods (1998), "Reading Jeanette Winterson Writing," 'I'm Telling You Stories: Jeanette Winterson and the Politics of Reading, Eds. Helena Grice and Tim Woods. Rodopi, Amsterdam, pp. 1-12. 
KANG, Ning (2009), "Puritanism and its Impact upon American Values," Review of European Studies, no: 1:2, 148-51.

LACAN, Jacques (2005), Ecrits. Trans. Bruce Fink, Norton, New York and London.

LANGLAND, Elizabeth (1997), "Sexing the Text: Narrative Drag as Feminist Poetics and Politics in Sexing the Cherry," Narrative, 99-107.

MAKINEN, Merja (2005), The Novels of Jeanette Winterson, Palgrave Macmillan, New York.

MOORE, Lisa (1995), "Teledildonics: Virtual Lesbians in the Fiction of Jeanette Winterson," Sexy Bodies: The Strange Carnalities of Feminism. Eds. Elspeth Probyn and E. A. Grosz. Routledge, London and New York, pp. 104-27.

PALMER, Paulina (1993), Contemporary Lesbian Writing: Dreams, Desire, Difference, Open University Press, Buckingham.

PILCHER, Jane and Imelda Whelehan (2004), 50 Key Concepts in Gender Studies, Sage Publishing, London.

"PURITANISM."<http://www.britannica.com/topic/Puritanis $\mathrm{m}>10$ August 2015.

WATKINS, Susan (2000), Twentieth-Century Women Novelists: Feminist Theory into Practice, Palgrave Macmillan, New York. London.

WINTERSON, Jeanette (1989), Sexing the Cherry, Vintage, 